\title{
Rights in the Australian federation
}

\author{
Nicholas Aroney ${ }^{*}$ and James Stellios ${ }^{* *}$
}

\begin{abstract}
The Australian Constitution is unique among constitutional instruments. It was primarily designed to federate self-governing British colonies within the British constitutional tradition and to establish institutions of federal government. As such, the constitutional instrument does not contain an entrenched Bill of Rights. Yet, Australia has been a stable federal democracy since its establishment in 1901 and, by international standards, it is consistently assessed as maintaining high levels of personal freedom, political rights, civil liberties and the rule of law. This article considers the place of rights in the Australian federation against Australian constitutional history and its constitutional context.
\end{abstract}

Keywords

Australian Constitution; Bill of Rights; constitutional rights; implied rights; federalism; separation of powers; judicial independence; democracy; freedom of interstate trade; freedom of religion; property rights; right to trial by jury.

The Commonwealth of Australia has been a stable federal democracy since its establishment in 1901. By international standards, Australia is consistently assessed as maintaining high levels of personal freedom, political rights, civil liberties and the rule of law. ${ }^{1}$ This is despite the fact that Australia does not have a constitutionally entrenched Bill of Rights, and only two Australian jurisdictions, the State of Victoria and the Australian Capital Territory, have enacted Statutory Charters of Rights. ${ }^{2}$ The Constitution of the Commonwealth of Australia contains only a small number of constitutional limitations on power that protect individual rights, and most of these protections apply only to the Commonwealth and not to the states. Why is this so, and how has Australia maintained high standards of personal freedom and the rule of law without a national Bill of Rights that binds both the Commonwealth and the States?

The primary objective of the Australian Constitution was to create the political institutions necessary for the establishment of a federation of the six constituent colonies that had

\footnotetext{
* Professor of Constitutional Law, The University of Queensland. The support of Australian Research Council grant FT100100469 is gratefully acknowledged. Thanks are also due to Terry East for his very capable research assistance.

** Professor, Law School, Australian National University. Part of this article benefited from the Australian Research Council's Discovery Projects funding scheme: DP140101218.

${ }^{1}$ World Justice Project, Rule of Law Index (Washington DC, 2015), p.8; Freedom House, Freedom in the World 2017 (Washington DC, 2017), p. 20.

${ }^{2}$ Human Rights Act 2004 (ACT); Charter of Human Rights and Responsibilities Act 2006 (Vic).
} 
occupied the Australian continent since before the mid nineteenth century. ${ }^{3}$ Most of the provisions of the Constitution are concerned with defining the nature and composition of those institutions and conferring powers and functions upon them. The two essential means by which the Constitution achieves this are the construction of a Parliament consisting of two houses representing the people of the Commonwealth and the people of the States (Sections 7 and 24) and the conferral of specific legislative powers on the Commonwealth with a guarantee that the Constitutions and general powers of the States would continue subject to the Constitution (Sections 51, 52, 106 and 107). ${ }^{4}$ The goal of the framers of the Constitution was to establish the Commonwealth and the States as partly independent, partly interdependent, self-governing political communities.

Because the Australian Constitution is primarily concerned with establishing the institutional foundations of a federal commonwealth, the limitations on power imposed by the Constitution are chiefly directed to maintaining an effectively operating federal system. ${ }^{5}$ The Constitution does not contain a general bill of rights because at the time it was drafted the prevailing view was that properly functioning systems of representative and responsible government at a Commonwealth and State level would, on the whole, provide adequate protection for civil and political rights. ${ }^{6}$ Sir Owen Dixon, one of Australia's most distinguished judges, put it this way:

The framers of the Australian Constitution were not prepared to place fetters upon legislative action, except and in so far as it might be necessary for the purpose of distributing between the States and the central government the full content of legislative power. The history of their country had not taught them the need of provisions directed to the control of the legislature itself. ${ }^{7}$

At the time that the Australian Constitution was being drafted, the general climate of opinion, as Jeffrey Goldsworthy has observed, had come to regard parliamentary democracy as the key to a more just and prosperous future. ${ }^{8}$ There was not the same concern to limit the powers of government to protect rights that had motivated the American antifederalists to insist upon a bill of rights as a condition of the ratification of the US Constitution in the late eighteenth century. Sir Daryl Dawson, a distinguished Justice of the High Court of Australia, put it this way:

[T] hose responsible for the drafting of the Constitution saw constitutional guarantees of freedoms as exhibiting a distrust of the democratic process. They preferred to place their trust in Parliament to preserve the nature of our society and regarded as undemocratic guarantees which fettered its powers. Their model in this respect was, not the United States Constitution, but the British Parliament, the supremacy of which was by then settled constitutional doctrine. ${ }^{9}$

\footnotetext{
${ }^{3}$ See N. Aroney, The Constitution of a Federal Commonwealth: The Making and Meaning of the Australian Constitution, Cambridge University Press, 2009, ch 5.

${ }^{4}$ Ibid., chs 8 \& 10 .

5 N. Aroney, P. Gerangelos, J. Stellios \& S. Murray, The Constitution of the Commonwealth of Australia: History, Principle and Interpretation, Cambridge University Press, 2015, pp. 282-287.

${ }^{6}$ For a range of views on whether national constitutions such as Australia's should contain a comprehensive bill of rights, see T. Campbell, J. Goldsworthy \& A. Stone (Eds.), Protecting Human Rights: Instruments and Institutions, Oxford University Press, 2003.

${ }^{7}$ O. Dixon, Jesting Pilate, Law Book, 1965, p. 102.

8 J. Goldsworthy, 'The Constitutional Protection of Rights in Australia', in G. Craven (Ed.), Australian Federation: Towards the Second Century, Melbourne University Press, 1992, pp. 151-8.

${ }^{9}$ Australian Capital Television Pty Ltd v Commonwealth (1992) 177 CLR 106, 186; see also 135-136.
} 
As a consequence, even when the Constitution protects rights or freedoms of one kind, the protections are prohibitions on the exercise of legislative and other forms of governmental power rather than assertions of personal rights or freedoms. The protections are also usually shaped, in one way or another, by federal considerations. Section 116 of the Constitution is an example. It provides:

The Commonwealth shall not make any law for establishing any religion, or for imposing any religious observance, or for prohibiting the free exercise of any religion, and no religious test shall be required as a qualification for any office or public trust under the Commonwealth.

Section 116 thus applies only to the Commonwealth, leaving the States free to exercise the powers they possessed, as colonies, prior to federation. Its purpose and operation are perhaps best captured by Gaudron J in Kruger $v$ The Commonwealth:

By its terms, s 116 does no more than effect a restriction or limitation on the legislative power of the Commonwealth. It is not, 'in form, a constitutional guarantee of the rights of individuals'. It does not bind the States: they are completely free to enact laws imposing religious observances, prohibiting the free exercise of religion or otherwise intruding into the area which s 116 denies to the Commonwealth. It makes no sense to speak of a constitutional right to religious freedom in a context in which the Constitution clearly postulates that the States may enact laws in derogation of that right. It follows, in my view, that s 116 must be construed as no more than a limitation on Commonwealth legislative power. ${ }^{10}$

Section 116 also operates as a fetter on legislative power, rather than a positive affirmation of the right to freedom of religion. As such, it presupposes a background legislative power vested in the Commonwealth, even though the topic of 'religion' does not appear in the list of federal legislative powers in Section 51 of the Constitution.

The limitation of Section 116 to the Commonwealth was very deliberate. Early in the framers' deliberations it was proposed that the Constitution contain two clauses on the topic of religion, one which bound only the States and protected only the free exercise of religion, and another which bound the Commonwealth and prohibited any law that established any religion, gave preferential recognition to any religion, or prohibited the free exercise of any religion. ${ }^{11}$ It was later proposed that the scope of the prohibition be reframed and changed so that it applied to both the Commonwealth and the States. ${ }^{12}$ However, the entire clause, including this extension to it, was resisted on a range of grounds. The most decisive of these objections was that to place limits on the States would be inconsistent with one of the fundamental principles of the federation, which was that the States were to "retain all such powers as they do not hand over to the Commonwealth". ${ }^{13}$ The main proponent of the freedom of religion clause, Henry Bournes Higgins, saw the point and refocused his energies on convincing the members of the federal convention to adopt a clause that would bind only the Commonwealth. Section 116, which applies only to the Commonwealth, was the result. ${ }^{14}$

\footnotetext{
${ }^{10}$ Kruger v The Commonwealth (1997) 190 CLR 1, 60, 124-25.

${ }^{11}$ R. G. Ely, 'Andrew Inglis Clark and Church-State Separation', Journal of Religious History, Vol. 8, No. 3, 1975, p. 285.

12 Official Record of the Debates of the Australasian Federal Convention, Melbourne, 8 February 1898, 658, 664.

${ }^{13}$ Ibid., 662.

${ }^{14}$ N. Aroney, P. Gerangelos, J. Stellios \& S. Murray, The Constitution of the Commonwealth of Australia: History, Principle and Interpretation, Cambridge University Press, 2015, pp. 338-341.
} 
Section 51(xxxi) of the Constitution is similar. It provides that the Commonwealth Parliament shall have power to make laws with respect to "the acquisition of property on just terms from any State or person for any purpose in respect of which the Parliament has power to make laws". The primary purpose of Section 51(xxxi) is to confer legislative power on the Commonwealth. However, it also restricts the power of the Commonwealth to legislate with respect to the acquisition of property by requiring that the acquisition must be on "just terms", which means that fair compensation must be paid for the property acquired and that the compensation to be paid must be assessed in procedurally fair manner. ${ }^{15}$ Section 51(xxxi) thus operates as a control on Commonwealth power, but like Section 116, has no application to the States.

Two other important limiting provisions in the Constitution are Sections 80 and 92. Section 80 requires that "trial on indictment of any offence against any law of the Commonwealth shall be by jury" and Section 92 stipulates that "trade, commerce, and intercourse among the States ... shall be absolutely free". Both sections limit the capacity of the Commonwealth to regulate the relevant subject matter, although Section also binds the States because, as will be explained, freedom of interstate trade and commerce was one of the central objectives of the federation.

The Commonwealth is able, within the scope of its legislative powers (see Sections 51 and 52 ), to create criminal offences tried before federal and state courts. Section 80 requires that any trial on indictment for such an offence must be by jury and is to be held in the State where the offence was committed. The reason for including the provision is unclear. Most obviously, it might be seen as protecting the rights of the accused to be judged by his or her peers. However, much of the case law in Australia does not support such a view. For example, the provision can be avoided by Parliament prescribing that a trial proceed other than on indictment, and the accused cannot waive the requirement in Section 80 in favour of trial by judge alone. These interpretations are incongruent with a view of Section 80 as protecting the liberty interests of the accused.

Alternative views of the purpose of Section 80 are available. Consistently with the broader federal architecture of the Constitution, Section 80 might have been intended as a structural provision to provide the Commonwealth with a vehicle for the administration of criminal justice at the federal level. ${ }^{16}$ Without its inclusion, there may have been doubt as to whether federal offences could be tried by a panel of lay people in the English tradition of that institution. Furthermore, it might be seen as guaranteeing democratic participation in the administration of criminal justice by requiring the trial to be held in the State where the offence was committed. As emphasised recently by Justice Gageler in Alqudsi v The Queen, Section 80 "has the result that the democratic participants in the requisite trial by jury will ordinarily in practice be people of that State". ${ }^{17}$

Given the primarily federal purpose of the Australian Constitution, the inapplicability of Section 80 to State offences and the uncertainty of its purpose, it is not surprising that aspects of these alternative explanations have emerged to impede interpretations that are protective of the accused.

\footnotetext{
${ }^{15}$ Ibid., 307-310.

${ }^{16}$ See J. Stellios, 'The Constitutional Jury: “A Bulwark of Liberty”?', Sydney Law Review, Vol. 27, 2005, pp. $113-142$.

${ }^{17}$ (2016) 258 CLR 203, 256-257.
} 
The Commonwealth also has power to make laws with respect to "trade and commerce ... among the States" (s 51 (i)). Section 92 stipulates that it must not do so in a way that interferes with freedom of interstate trade, commerce and intercourse. However, unlike the other provisions considered so far, Section 92 is unique in that it applies to the States as well. They too are not able to make laws that interfere with freedom of interstate trade, commerce and intercourse. This is because freedom of interstate trade was regarded as one of the most fundamental objectives of federation, a principle that both the Commonwealth and the States are required to respect. ${ }^{18}$

In this way, even the apparently rights-protective limitations on power that exist in the Australian Constitution are best understood as aspects of its federal architecture. ${ }^{19}$ Most of the protections are deliberately addressed only to the Commonwealth on the assumption that, unless some federating imperative makes it necessary, any controls on the powers of the State governments are matters for the peoples of the States to address through their respective State Constitutions and parliamentary institutions. And the rights-protective limitations that apply to both Commonwealth and State power, such as Section 92, have an obvious federal rationale.

At one point in time, the framers of the Australian Constitution did consider the inclusion of a more far-reaching provision. In early drafts of the Constitution, there was a section partially modelled on two provisions of the United States Constitution, namely Article IV and the Fourteenth Amendment. The Fourteenth Amendment was inserted into the American Constitution to protect the rights of emancipated slaves following the Civil War (1861-65). In language very similar to the fourteenth amendment, the draft provision considered by the framers of the Australian Constitution prohibited any State from making or enforcing any law "abridging any privilege or immunity of the citizens of other States" or denying to any person "the equal protection of the laws". ${ }^{20}$ Unlike the restrictions on power considered so far, this draft clause was directed at the States, not the Commonwealth. However, the framers of the Australian Constitution eventually decided not to include such a far-reaching provision, opting instead for the more narrowly-worded Section 117, which provides:

A subject of the Queen, resident in any State, shall not be subject in any other State to any disability or discrimination which would not be equally applicable to him if he were a subject of the Queen resident in such other State. ${ }^{21}$

The framers' reasons for rejecting the wider language of the original proposal were several. ${ }^{22}$ One was that there was no pressing need for such a provision because the special circumstances that the United States faced following the Civil War did not obtain in Australia, and it was thought imprudent to include a provision of such generality into the Constitution without specific reason for it. A second reason was that such a rule might

\footnotetext{
${ }^{18}$ N. Aroney, P. Gerangelos, J. Stellios \& S. Murray, The Constitution of the Commonwealth of Australia: History, Principle and Interpretation, Cambridge University Press, 2015, pp. 310-313.

${ }^{19}$ See W Harrison Moore, 'The Commonwealth of Australia Bill', Law Quarterly Review, Vol. 16, 1900 , p. 40.

${ }^{20}$ Official Report of the National Australasian Convention Debates, Sydney, 1891, 962; Official Report of the National Australasian Convention Debates, Adelaide, 1897, 1241.

${ }^{21}$ On the interpretation of Section 117, see Street v Queensland Bar Association (1989) 168 CLR 461; Goryl v Greyhound Australia Pty Ltd (1994) 179 CLR 463; Sweedman v Transport Accident Commission (2006) 226 CLR 362.

${ }^{22}$ Official Record of the Debates of the Australasian Federal Convention, Melbourne, 28 January 1898, 246-8; 8 February 1898, 664-691; 3 March 1898, 1780-1802; 11 March 1898, 2397.
} 
prevent the States from continuing to enact laws specifically directed at Chinese and South Pacific immigrants and indentured labourers. This anxiety was connected with a more general concern not to multiply the points at which the Constitution would interfere with the independent legislative powers of the States. A third reason concerned a fundamental disagreement about the nature of citizenship within the proposed federation. Some of the framers of the Australian Constitution wanted a kind of national citizenship to be established, but others insisted that in a federation there must be a "dual" citizenship of both the Commonwealth and the States. A majority of the framers concluded that the Constitution should remain silent on the question of citizenship, and leave the decision as to whether the States would continue to enact racially discriminatory laws in the hands of their elected Parliaments. The States and the Commonwealth did continue to enact such laws for several decades, but these were progressively repealed as community attitudes to such laws changed in the 1960s and 1970s. Moreover, although Australians would also continue formally to be "subjects of the Crown" until the Australian Citizenship Act 1948 (Cth) came into force in 1949 , an underlying idea of dual citizenship existed from the time of federation. ${ }^{23}$

There have been several attempts since federation to insert rights-protective provisions into the Constitution. None have been successful. In 1944, a proposal to insert guarantees of freedom of expression and to extend the freedom of religion provision to the States was rejected by a majority of voters nationally and in all but two States. ${ }^{24}$ In 1988, a proposal to insert guarantees of the right to vote, and to extend to the States the existing protections in relation to acquisition of property on just terms, jury trial and freedom of religion, failed by very substantial margins to secure a majority in any State. Attempts to introduce statutory human rights laws at a Commonwealth level in the 1970s and 1980s were also unsuccessful. ${ }^{25}$ Since then, Charters of Rights that provide for a "weak" form of judicial review have been adopted in two Australian jurisdictions, ${ }^{26}$ but not elsewhere. In 2009, a National Human Rights Consultation recommended in favour of a range of reforms, including a (non-constitutional) Human Rights Act, ${ }^{27}$ but the Commonwealth decided only to implement the educative, administrative and procedural aspects of the recommendations, including provision for greater parliamentary scrutiny of legislation. ${ }^{28}$ The debate over a bill of rights in Australia continues, shaped by evaluations of Australia's human rights record, which though not perfect is exceptionally good by world standards. ${ }^{29}$

Despite the framers' reticence in relation to rights, and the unwillingness of the Australian people to approve the insertion of additional rights-protecting provisions into the Constitution, the High Court has found that the Constitution contains certain implied limitations on power said to be derived by inference from the text, structure, principles and purposes of the Constitution. These include a system of reciprocal intergovernmental immunities protecting the Commonwealth from State interference and the States from undue

\footnotetext{
${ }^{23}$ See B. Galligan \& W. Roberts, Australian Citizenship, Melbourne University Press, 2004.

${ }^{24}$ According to section 128 of the Constitution, the Constitution can only be amended by referendum at which a majority of Australian voters and a majority of voters in a majority of States approve the proposed change.

${ }^{25}$ G. Williams, A Charter of Rights for Australia, University of New South Wales Press, 2007, pp. 57-62.

${ }^{26}$ Human Rights Act 2004 (ACT); Charter of Human Rights and Responsibilities Act 2006 (Vic). For assessments, see C. Campbell and M. Groves, Australian Charters of Rights a Decade On, Federation Press, 2017.

${ }^{27}$ National Human Rights Consultation: Report (Commonwealth of Australia, 2009).

${ }^{28}$ Human Rights (Parliamentary Scrutiny) Act 2011 (Cth).

29 T. Campbell, J. Goldsworthy \& A. Stone, Protecting Rights without a Bill of Rights: Institutional Performance and Reform in Australia, Ashgate, 2006.
} 
Commonwealth interference ${ }^{30}$ and a set of rules maintaining the separation of judicial power from executive and legislative power and protecting the integrity of the courts. ${ }^{31}$ The High Court has also held that the democratic features of the Constitution necessarily imply that the Commonwealth and the States cannot unjustifiably interfere with freedom of communication concerning political matters. ${ }^{32}$

Individual members of the High Court have at times also suggested that additional civic freedoms might be implied by the democratic features of the Constitution, such as freedom of association and freedom of assembly; however, none of these propositions has secured the support of a majority of the High Court. What the High Court has never done is to adopt the suggestion of Sir Robin Cooke, then of the New Zealand Court of Appeal, that the legislative powers of Parliaments within the Westminster tradition might be restrained by judiciallyenforceable rights deeply rooted in the common law. ${ }^{33}$ In Durham Holdings Pty Ltd $v$ NSW, for example, the High Court of Australia rejected the argument that the common law gives rise to a limitation on the capacity of the Parliament of the State of New South Wales to deprive a person of his or her property without just, or any properly adequate, compensation. ${ }^{34}$ As the Court pointed out in that case, the existence of limitations on the powers of Australian Parliaments have to be found in the text and structure of the Constitution itself and not in principles extraneous to the document. ${ }^{35}$

In these respects the High Court has been generally attentive to the fundamentally federal nature and design of the Australian Constitution. However, the Constitution's treatment of the powers and composition of the courts marks a partial exception to this general tendency. Part of the reason is that the judiciary in Australia is the most integrated of the three arms of government. Modelled on Art III of the United States Constitution, Chapter III of the Constitution establishes a federal judiciary that is distinct from the State judicial systems. However, there are two important departures from the United States model. First, for reasons of expense and efficiency, the framers of the Australian Constitution adopted the "autocthonous expedient" "36 of permitting the Commonwealth Parliament to vest federal jurisdiction in State courts. Secondly, the High Court of Australia sits at the apex of the Australian judicial system and determines appeals from federal and State courts. Although the framers rejected American-style due process and equal protection clauses, these constitutional structures for the exercise of judicial power have provided opportunities for judicially-created implications protecting the judicial process. The separate creation and identification of judicial power in Chapter III of the Constitution has given rise to two separation of judicial power limitations on the Commonwealth Parliament: that federal judicial power can only be exercised by courts and that those courts can only exercise judicial or incidental non-judicial power. Additionally, the autocthonous expedient of permitting State courts to exercise federal judicial power has been seen as justifying a limitation on State Parliaments preventing the enactment of laws that would be incompatible with their exercise of federal power. These limitations operate to protect the independence and impartiality of the Australian courts, the fairness of the procedure offered to litigants, and the openness and

\footnotetext{
${ }^{30}$ Melbourne Corporation v Commonwealth (1947) 74 CLR 31.

${ }^{31} R$ v Kirby; Ex parte Boilermakers' Society of Australia (1956) 94 CLR 254.

${ }^{32}$ Australian Capital Television Pty Ltd v Commonwealth (1992) 108 CLR 577.

${ }^{33}$ Eg, Taylor v New Zealand Poultry Board [1984] 1 NZLR 394, 398; Fraser v State Services Commission [1984] 1 NZLR 116, 121.

${ }^{34}$ Durham Holdings Pty Ltd v NSW (2001) 205 CLR 399, 408-10, 418-23, 433.

${ }^{35}$ Ibid., 410, 431-2.

${ }^{36}$ The Queen v Kirby; Ex parte Boilermakers' Society of Australia (1956) 94 CLR 254, 268 (Dixon CJ, McTiernan, Fullagar and Kitto JJ).
} 
transparency of the process for administering justice. In the absence of entrenched bills of rights, these limitations have been said to offer "the Constitution's only general guarantee of due process." 37

The clearest basis for such implications draws from the federal character of the Constitution. Indeed, the seminal cases supporting these limitations ground them in the federal character of the Constitution: the limitations are required to protect the judiciary to perform its constitutional functions of adjudicating the federal distribution of powers between the Commonwealth and the States. ${ }^{38}$ These justifications resonate strongly with the views of the framers of the Constitution when designing the judicial provisions. ${ }^{39}$ Nonetheless, there have been liberty-protecting rationales advanced to support these limitations. The judiciary and judicial power have been viewed as safeguarding liberty through the independent determination of disputes about basic rights, ${ }^{40}$ and in protecting the individual from detention in the custody of the state. ${ }^{41}$ Thus, it has been held that the adjudgment and punishment of criminal guilt requires an exclusive exercise of judicial power by a court. ${ }^{42}$ As explained recently by Justice Gageler in Magaming $v$ The Queen:

Why that should be so is founded on deeply rooted notions of the relationship of the individual to the state going to the character of the national polity created and sustained by the Constitution ... . Chapter III of the Constitution ... reflects and protects a relationship between the individual and the state which treats the deprivation of the individual's life or liberty, consequent on a determination of criminal guilt, as capable of occurring only as a result of adjudication by a court. ${ }^{43}$

The federal character of the Constitution does not require these principles. Rather, this view of the role of the courts within a system of separated power is animated by a "concern for the protection of personal liberty lying at the core of our inherited constitutional tradition, which includes the inheritance of the common law". "Indeed, some judges have elevated this limitation to the status of a "constitutional immunity" 45 from the deprivation of liberty otherwise than through the ordinary curial process of adjudging and punishing criminal guilt. $^{46}$ It remains to be seen how rigorously these sentiments will be applied to federal legislative regimes for executive detention and court-ordered preventative detention.

The simultaneously federal and democratic character of the Australian Constitution is also to be seen in the complex electoral system that it establishes. Part of this complexity derives from the fact that the system of representative government operating at a Commonwealth

\footnotetext{
${ }^{37}$ Re Tracey; Ex parte Ryan (1989) 166 CLR 518, 580 (Deane J).

${ }^{38}$ See, for instance, The Queen v Kirby; Ex parte Boilermakers' Society of Australia (1956) 94 CLR 254, 276

(Dixon CJ, McTiernan, Fullagar and Kitto JJ); Forge v Australian Securities and Investments Commission (2006) 228 CLR 45.

${ }^{39}$ See James Stellios, The Federal Judicature: Chapter III of the Constitution (LexisNexis, 2010) 68-72.

${ }^{40}$ The Queen v Quinn; Ex parte Consolidated Food Corporation (1977) 138 CLR 1, 11 (Jacobs J).

${ }^{41}$ Chu Kheng Lim v Minister for Immigration, Local Government and Ethnic Affairs (1992) 176 CLR 1, 27 (Brennan, Deane and Dawson JJ).

${ }^{42}$ These limitations operate at their highest in relation to the Commonwealth Parliament. The State Parliaments may well have greater freedom to remove aspects of the criminal process from State courts.

${ }^{43}$ Magaming v The Queen (2013) 252 CLR 381, 400, 401.

${ }^{44}$ North Australian Aboriginal Justice Agency Ltd v Northern Territory (2015) 256 CLR 569, 610 (Gageler J).

${ }^{45}$ Chu Kheng Lim v Minister for Immigration, Local Government and Ethnic Affairs (1992) 176 CLR 1, 28 (Brennan, Deane and Dawson JJ).

${ }^{46}$ See also the important statement of Gummow J in Fardon v Attorney-General (Qld) (2004) 223 CLR 575, 613-14.
} 
level is constructed upon the pre-existing systems of parliamentary government established at a State level. Thus, for example, although Section 24 provides that the Commonwealth House of Representatives consists of members "directly chosen by the people of the Commonwealth" and further stipulates that "the number of the members of the House chosen in the several States shall be in proportion to the respective numbers of their people", it also provides that "five members at least shall be chosen in each Original State". Moreover, although the Commonwealth Parliament was given ultimate control over the qualifications of electors and candidates for federal office (Sections 8 and 30), the size and location of federal electoral divisions (Sections 7 and 29) and the organisation and conduct of federal elections (Sections 7, 9 and 31), prior to Commonwealth determination of these matters, the rules applying in the States were applied to the Commonwealth.

This adaptation of principles of democracy to principles of federalism has shaped the way in which the High Court has interpreted the Constitution in relation to civil and political rights. Thus, the Court has held that there are limits to the Commonwealth's ability to alter the right to vote and the scope of the franchise (ie, so as to maintain full adult franchise). ${ }^{47}$ However, a majority of the Court has rejected the proposition that democratic principle requires that federal electoral divisions must be approximately equal in population because to do so would be to ignore the way in which principles of majoritarian democracy are qualified by principles of federalism under the Constitution. ${ }^{48}$ This adaptation of democracy and federalism is clearly seen in Section 7, which requires that each Original State must be equally represented in the Senate notwithstanding very significant differences in the populations of each State. The adaptation of federalism and democracy is also seen very dramatically in the prescribed process for formal amendment of the Constitution, Section 128 of which requires that any proposal to alter the Constitution is simultaneously approved by a majority of voters in the Commonwealth as a whole and a majority of voters in a majority of States.

Given the importance of this adaptation of federalism to democracy, it may come as a surprise that the High Court has held that the implied freedom of political communication binds both the Commonwealth and the States and applies to the discussion of political matters at both levels of government. The extension of the implied freedom to the States is based on the proposition that although the Constitution establishes a system of representative democracy only for the Commonwealth, Australian federal and state politics are so integrated that a distinction cannot be drawn between the discussion of politics at one level of government from discussion at another level. Although this appears to adapt the implied freedom to the federal nature of the system, it has a nationalising effect. This is because the implied freedom is conceptually grounded upon an essentially unitary conception of the Australian democratic system, predicated upon a direct relationship between "the people" and "the government", and therefore requires the same uniform standard, derived from the Commonwealth Constitution, to be applied to both the Commonwealth and the States. However, this conclusion sits somewhat uneasily with the system of federal democracy that the Constitution establishes, involving a complex set of interlocking but distinct relationships between the people of each State, the people of the Commonwealth, and their respective constitutions and governments at a Commonwealth and State level.

\footnotetext{
${ }^{47}$ Roach v Electoral Commissioner (2007) 233 CLR 162; Rowe v Electoral Commissioner (2010) 243 CLR 1.

${ }^{48}$ McGinty v Western Australia (1996) 186 CLR 140. See N. Aroney, 'Democracy, Community and Federalism in Electoral Apportionment Cases: The United States, Canada and Australia in Comparative Perspective', University of Toronto Law Journal, Vol. 58, No. 4, 2008, p. 421-480.
} 
For this reason it may be better to conceive the foundation of the implied freedom of political communication as based rather in a set of implied intergovernmental constraints, as the High Court seemed to envisage in its early approach to civil and political rights. ${ }^{49}$ Here the idea would be that, building on the doctrine of intergovernmental immunities, it lies beyond the power of the Commonwealth and the States to interfere with the independent functioning of the democratic systems of each other. On this view, it might also lie beyond the competence of the Commonwealth to interfere with the proper functioning of the democratic system operating at a federal level because the Commonwealth is itself constitutively federal, incorporating the component democratic bodies politic of the States into its own body politic in a way that maintains the integrity of each State as a self-governing body politic. If the implied freedom were to be reconceived in this way, there would be less warrant for an implied limitation on the capacity of the States to interfere with their own democratic systems, except that the integrity of the federal system is dependent on the integrity of the State systems as well. The High Court is of course far from reconceptualising the implied freedom in this way, but such an approach would at least cohere better, it is submitted, with the federal nature of the Constitution than the existing rationale. ${ }^{50}$

\footnotetext{
${ }^{49} R v$ Smithers; Ex parte Benson (1912) 16 CLR 99.

${ }^{50}$ J. Stellios, 'Using Federalism to Protect Political Communication: Implications from Fedreal Representative Government', Melboume University Law Review, Vol. 31, 2007, 239-265.
} 